\title{
Assessment of Chainsaw Operators Training in Andalusia (Spain)
}

\author{
María del Carmen Pardo Ferreira, Francisco Salguero Caparrós, Jesús Antonio Carrillo \\ Castrillo, Ana Isabel Marín García, Juan Carlos Rubio Romero
}

\begin{abstract}
The chainsaw, as a work equipment, is considered one of the most dangerous in the field of occupational health and safety. The chainsaw is especially used in the forestry sector, although it is also used in other different sectors such as agriculture, construction or gardening. This study was carried out using an ad-hoc questionnaire as a research tool in order to assess the weaknesses in the training received by workers who use chainsaws in Andalusia, Spain, since it has never been addressed before. To achieve the objective set, the questionnaire was completed by 378 operators working with chainsaw and their responses were analysed. The results of this study show that there are obvious shortcomings related to work with chainsaws in very significant aspects for the occupational health and safety. Of special importance is the lack of training detected on rescue techniques and work at height, since these are aspects of special risk for workers' health that could cause accidents with severe injuries. Also, a common denominator in all aspects studied was the lack of safety inspections and the state of the equipment to be used. These results evidence that there is a need to regulate chainsaw operator training.
\end{abstract}

Keywords: chainsaw worker, learning requirements, occupational health and safety, labour risk, ABA International

\section{Introduction}

The chainsaw, as a work equipment, is considered one of the most dangerous in the field of occupational health and safety (Potočnik and Poje 2017, Robb and Cocking 2014, Enez et al. 2014, Cabeças 2006). So much so that, as assert Ambrosio et al. (2001), it is observed that the risk in the use of the chainsaw is of the order of 4 or 5 times higher than that of other risks in sectors such as agriculture.

This work equipment is used especially in specific sectors such as forestry, although it is also used in other sectors such as agriculture, construction or gardening (Hammig and Jones 2015, Cividino et al. 2012).

Despite the technological advances introduced in this work equipment, the inadequate training of workers in the use of the chainsaw continues to be one of the main problems (Albizu-Urionabarrenetxea et al. 2013). The most dangerous activity for operators is felling or cutting trees. Specifically, the three most common types of fatality are due to being hit by a tree or branch, slips and trips, and cut by the chainsaw (Robb and Cocking 2014).

Specifically, in Spain, work in the forestry sector shows a significantly higher accident rate than other high risk sectors. The workers who deal with the felling of trees are the most exposed to the risks in the forestry sector. These aspects reveal that forestry work is very dangerous (Robb and Cocking 2014, AlbizuUrionabarrenetxea et al. 2013, Lefort et al. 2003, Bell 2002, Peters 1991). In the semi-mechanised logging operations, the great majority of accidents are generally caused by chainsaws, not only in the logging phase (Albizu-Urionabarrenetxea et al. 2010, Neely and Wilhelmson 2006, Nieuwenhuis and Lyons 2002, Shaffer and Milburn 1999, Axelsson 1998, Peters 1991). The main risk factors that have been identified and studied in relation to the use of the chainsaw are related to experience (Wang et al. 2003, Lefort et al. 2003, Bentley et al. 2002, Shaffer and Milburn 1999), age (Neely and Wilhemson 2006, Wilhelmson et al. 2005, Thelin 2002, Salminen et al. 1999), seasonality and type 
of company (Picchio et al. 2010, Montorselli et al. 2010, Wang et al. 2003), frequency with which the chainsaw is used (Albizu-Urionabarrenetxea et al. 2013, Lilley et al. 2002), training (Cividino et al. 2015, Blombäck et al. 2003), use and maintenance of protective equipment (Albizu-Urionabarrenetxea et al. 2013), work technique (Thelin 2002, Salminen et al. 1999, Peters 1991), work at height (Tamboreno et al. 2015, Robb and Cocking 2014, Tamboreno 1989), use of winches (Bellmunt 1986) and intervention in emergency work (Robb and Cocking 2014).

Further, some of these detailed factors may result in workers being unduly exposed to unacceptable risks. In this context, the perception of risk is articulated as of vital importance in the use of this work equipment. Thus, it is essential that workers receive a good training that includes both the theoretical knowledge needed and practical exercises on work techniques (Albizu-Urionabarrenetxea et al. 2013). Similarly, it is important to improve the training content on occupational safety and health focused on the use of chainsaw that workers receive during general job training. In this way, as stated by authors such as Damalas et al. (2019) and Allman et al. (2017), lifelong education and training is a key element to reduce accidents. Likewise Landekić et al. (2018) stated that vocational training in modern forestry emphasises the introduction of specialised training in the use of a chainsaw, certified by accredited professionals in the field.

Regarding the training for chainsaw operators, there is no compulsory training in Europe for workers using a chainsaw in their work beyond the requirements set by Directive 2009/104/EC of 16 September 2009 concerning the minimum safety and health requirements for the use of work equipment by workers at work (European Parliament and of the Council 2009). Nonetheless, there is voluntary training regulated through Professional Qualifications and Professional Certificates. In this sense, specifically in Spain, there are vague mandatory specifications about the type of training, content and duration, just according to the direct translation of the EU Framework Directive (Pardo-Ferreira et al. 2017, Albizu-Urionabarrenetxea et al. 2010). Therefore, there are no minimum clear and concrete specifications of mandatory status concerning the skills and training that chainsaw operators should acquire in terms of safety and health. However, these specifications exist in the case of other dangerous equipment such as removable tower cranes, mobile cranes or various activities in the construction, metal industry, and even in work at height.
Therefore, the aim of this paper is to assess the weaknesses in the training received by chainsaw workers in Andalusia, Spain. To do this, based on the theoretical knowledge that these workers should receive, a questionnaire has been developed to evaluate the weaknesses in the training received by chainsaws workers, since, as Albizu-Urionabarrenetxea et al. (2010) indicated, it is an effective method in the collection of field data for the purpose of implementing the preventive programme. The results obtained will help to establish minimum mandatory training for chainsaw operators, filling the legal gap that currently exists in Spain. In fact, we believe that the findings of this research would be useful for future research focused on needs for the implementation of periodic safety training, the precise time to evaluate the transfer of training received by chainsaw operators as well as the characteristics of effective safety training.

This study has been developed by the University of Malaga as partner, along with other entities from various regions throughout Europe, within the project VET-SAFETY project 2014-2017 and the EU Erasmus + programme \& ABA International.

\section{Materials and Methods}

This study was carried out using an ad-hoc questionnaire as a research tool. The following documents were used as the main sources of information in the questionnaire design:

$\Rightarrow$ ABA International-European Chainsaw Standards (ABA 2012)

$\checkmark$ ECC 1: Chainsaw Maintenance \& Crosscutting Techniques (Robb 2011a)

$\checkmark$ ECC 2: Basic Tree Felling Techniques (Robb 2011b)

$\checkmark$ ECC 3: Advanced Tree Felling Techniques (Robb 2011c)

$\checkmark$ ECC 4: Windblown \& Damaged Trees (Robb 2011d)

$\Rightarrow$ Doctoral dissertation by Albizu Urionabarrenetxea (2012): Diagnóstico de la seguridad en los aprovechamientos forestales a partir de registros empresariales, bases de datos oficiales y muestreos de campo: propuestas de actuación

$\Rightarrow$ Professional forestry worker qualification AGA343_2, recognised by the Spanish Ministry of Education, Culture and Sport, and its corresponding professional forestry worker certificate AGAR0108, recognised by the Spanish Ministry of Labour and Social Security (2011) 
Table 1 Number of items and contents of each part of the questionnaire

\begin{tabular}{|c|c|c|c|c|}
\hline & Sections & Subjects & Number of questions or items & Total \\
\hline \multirow{9}{*}{$\begin{array}{l}\text { Preliminary } \\
\text { section }\end{array}$} & \multirow{4}{*}{ Personal information } & Sex & 1 & \multirow{9}{*}{9 questions } \\
\hline & & Age & 1 & \\
\hline & & Type of company & 1 & \\
\hline & & Frequency of use of a chainsaw & 1 & \\
\hline & \multirow{5}{*}{ Open-ended questions } & Time worked with a chainsaw & 1 & \\
\hline & & Learning way of chainsaw use & 1 & \\
\hline & & General education & 1 & \\
\hline & & Training on health and safety & 1 & \\
\hline & & Training on use and operation of a chainsaw & 1 & \\
\hline \multirow{7}{*}{\multicolumn{2}{|c|}{ Questionnaire section }} & Personal protective equipment & 3 & \multirow{7}{*}{25 items } \\
\hline & & Chainsaw & 2 & \\
\hline & & Work techniques & 7 & \\
\hline & & $\begin{array}{c}\text { Work at height without mobile elevating work } \\
\text { platforms }\end{array}$ & 3 & \\
\hline & & Mobile elevating work platforms (mewps) & 5 & \\
\hline & & Winches & 3 & \\
\hline & & Emergency & 2 & \\
\hline
\end{tabular}

$\Rightarrow$ The technical standards of the Spanish National Institute of Occupational Health and Safety, like those on Mobile lifting platforms (Tamboreno et al. 2015), Blocks and tackles, hoists and pulleys (Bellmunt 1986) and ladders (Tamboreno 1989).

From these selected sources of information, the essential skills of workers who use the chainsaw at work were obtained. Subsequently, these skills would be evaluated through a questionnaire focused on the training and practices that these workers currently have.

For this purpose, the questionnaire developed was assessed by a panel of experts, using the Individual Aggregate Method proposed by Corral (2009) to validate it. Thus, five experts were selected, two more than the required minimum. They used a previously adapted version of the evaluation form model proposed by Corral (2009). This form assessed general aspects of the questionnaire analysing clarity, coherence, language and bias of both the personal information requested and the open-ended questions and items. Finally, the necessary changes resulting from the evaluation were carried out and a final version of the questionnaire was obtained.
The questionnaire was divided into two parts. The first part comprised nine questions: The first four aimed at gathering information about the sociodemographic data of the sample of participating workers. The other five questions were open-ended ones to find out their experience working with a chainsaw; how they learned to use it; their general training; occupational health and safety training; and specific training in how to use a chainsaw. The second part comprised 25 items, assessed using a 5-point Likert scale to represent the following options: Always (5), Almost Always (4), Sometimes (3), Hardly Ever (2) and Never (1). These 25 items were divided into 7 different sections, as per Table 1.

Finally, a space was included at the end of the document for possible comments by the workers.

As for the workers who completed the questionnaires, they worked in Andalusia (Spain) and used a chainsaw in their work. They completed the questionnaires during their workday on a voluntary basis. All of them worked directly or indirectly for the Andalusian government entities, which collaborated in the present study by sending the questionnaire to the workers and providing them with enough time to complete it properly. Once the questionnaires were received, they were 
examined and some were discarded based on different reasons such as: they were incomplete, the respondent chose more than one answer for the same item, they gave almost all the same answers, the answers were exactly the same as those of a colleague or the worker indicated that they never used a chainsaw. In this way, initially 474 questionnaires were received. These were examined and 96 were discarded. Finally, 378 questionnaires were obtained that would be analysed to extract the main results. Thus, a descriptive analysis of the information collected in the questionnaires was carried out and correlations between variables were analysed.

\section{Results}

This section presents all the information extracted from the questionnaires received. In the first place, the analysis of personal information and open-ended questions are presented, which allow characterising the workers who participated in the study by filling the questionnaire. These results are portrayed in different tables, showing the number of cases in each category, percentage and frequency out of a total of 378 questionnaires that were analysed. Second, the results of analysing the 25 items included in the questionnaire are presented. For this purpose, means $(\bar{x})$ and standard deviation $(\sigma)$ are also analysed. The »unknown « category shows the number of items not filled in by the respondents.

\subsection{Preliminary Section: Personal Information and Open-Ended Questions}

Regarding the personal information of the workers surveyed, results are shown in Table 2. Only three of the respondents were women. The respondents had an average age of 44 , with almost half the respondents (48\%) being aged between 40 and 49. Regarding the type of company where the surveyed workers perform their jobs, the results show that $95 \%$ of the workers were employed in the public sector. From the analysis of the frequency with which the workers used a chainsaw at work, it follows that most workers used chainsaws several months a year (53\%).

As for open-ended questions, the questions raised are presented in Table 3 as well as the results obtained in terms of their experience working with a chainsaw; how they learned to use it; their general training; occupational health and safety training; and specific training in how to use a chainsaw.

The results show that $64.9 \%$ of workers had between 11 and 30 years of experience using a chainsaw.
Table 2 Results of items on personal information

\begin{tabular}{|c|c|c|}
\hline Variable & Frequency & Percentage, \% \\
\hline \multicolumn{3}{|l|}{ Sex } \\
\hline Men & 375 & 99.2 \\
\hline Women & 3 & 0.8 \\
\hline \multicolumn{3}{|l|}{ Age } \\
\hline Unknown & 5 & 1.3 \\
\hline 20-29 years & 5 & 1.3 \\
\hline 30-39 years & 79 & 20.9 \\
\hline 40-49 years & 182 & 48.2 \\
\hline $50-59$ years & 100 & 26.5 \\
\hline More than 60 years & 7 & 1.8 \\
\hline \multicolumn{3}{|c|}{ Type of company } \\
\hline Unknown & 8 & 2.1 \\
\hline Private company & 2 & 0.5 \\
\hline Public company & 323 & 85.4 \\
\hline Public company and private company & 10 & 2.7 \\
\hline Emergency services & 27 & 7.2 \\
\hline Public company and self-employed & 3 & 0.8 \\
\hline Public company and emergency services & 5 & 1.3 \\
\hline \multicolumn{3}{|c|}{ Frequency of use of a chainsaw } \\
\hline Unknown & 29 & 7.7 \\
\hline Daily & 35 & 9.3 \\
\hline 2 or 3 times a week & 45 & 12 \\
\hline 1 time per week & 29 & 7.7 \\
\hline 1 time per month & 39 & 10.1 \\
\hline Several months a year & 201 & 53.2 \\
\hline
\end{tabular}

Also, it should be noted that only $31.5 \%$ of workers learned to use a chainsaw in training courses. In terms of their level of education, $23.8 \%$ did not indicate their level of education but just gave information on courses, for example, courses taught by training companies to improve the employability and knowledge of workers, by the Public Administration in Andalusia. Even 10.6\% indicated the training given by the company where they currently worked or had previously worked.

Further, as shown in Table 3, 87.3\% of the interviewees indicated that they had received occupational health and safety training and $79.9 \%$ indicated they had received some training on the use and operation of a chainsaw. The courses received consist of training in occupational health and safety, light machinery, accident procedures, fire extinction, safety in forestry work, 
Table 3 Results of the items on open-ended questions

\begin{tabular}{|c|c|c|}
\hline Variable & Frequency & Percentage, $\%$ \\
\hline \multicolumn{3}{|c|}{ How long have you been working with a chainsaw? } \\
\hline Not defined/Unknown & 34 & 9 \\
\hline 10 years or less & 91 & 24 \\
\hline Between 11 and 20 years & 142 & 37.6 \\
\hline Between 21 and 30 years & 103 & 27.3 \\
\hline More than 30 years & 8 & 2.1 \\
\hline \multicolumn{3}{|c|}{ How did you learn to use a chainsaw? } \\
\hline Unknown & 21 & 5.6 \\
\hline At work/the company & 127 & 33.6 \\
\hline Training courses & 119 & 31.5 \\
\hline Self-taught/alone/practicing & 82 & 21.7 \\
\hline From a co-worker & 16 & 4.2 \\
\hline From a relative & 13 & 3.4 \\
\hline \multicolumn{3}{|c|}{ General education } \\
\hline Unknown & 144 & 38.1 \\
\hline Basic education & 46 & 12.2 \\
\hline Compulsory secondary education & 5 & 1.3 \\
\hline Full secondary school & 10 & 2.7 \\
\hline Professional training & 16 & 4.2 \\
\hline Superior technician & 19 & 5 \\
\hline University & 8 & 2.1 \\
\hline Training company & 40 & 10.6 \\
\hline Courses & 90 & 23.8 \\
\hline \multicolumn{3}{|c|}{ Training on occupational health and safety (OHS) } \\
\hline Unknown & 47 & 12.4 \\
\hline Received training in $\mathrm{OHS}$ & 330 & 87.3 \\
\hline Not received training in $\mathrm{OHS}$ & 1 & 0.3 \\
\hline \multicolumn{3}{|c|}{ Training on the use and operation of a chainsaw } \\
\hline Unknown & 54 & 14.3 \\
\hline $\begin{array}{l}\text { Received training in use and operation } \\
\text { of chainsaw }\end{array}$ & 302 & 79.9 \\
\hline $\begin{array}{l}\text { Not received training in use and } \\
\text { operation of chainsaw }\end{array}$ & 22 & 5.8 \\
\hline
\end{tabular}

first aid, preventive measures in forestry, civil and hydraulic works, vertical work, pruning at heights, mobile elevating work platforms (MEWPs) and winches.

Table 4 shows the number of hours dedicated to occupational health and safety training by the workers who stated that they had received occupational health and safety training. Of the 378 operators working with
Table 4 Training devoted to occupational health and safety

\begin{tabular}{|l|c|c|}
\hline Occupational health and safety training time & Frequency & Percentage, \% \\
\hline Not received training in OHS & 1 & 0.3 \\
\hline Less than 25 hours & 62 & 16.3 \\
\hline Between 25 and 50 hrs & 69 & 18.2 \\
\hline Between 51 and 100 hrs & 92 & 24.3 \\
\hline Between 101 and 150 hrs & 17 & 4.6 \\
\hline More than 150 hrs & 24 & 6.3 \\
\hline Unknown & 66 & 17.5 \\
\hline Does not answer & 47 & 12.5 \\
\hline Total & 378 & 100 \\
\hline
\end{tabular}

chainsaw, 66 indicate they do not know the number of hours they have received in occupational health and safety training.

Meanwhile, as for the training in the use and operation of chainsaws, the workers that had received training on using a chainsaw mentioned having completed the following courses: professional chainsaw qualification; advanced chainsaw operator course; chainsaw operator course; chainsaw maintenance course; online chainsaw and scrub-clearing course; chainsaw and scrub-clearing course; safety in chainsaw tasks; cutting and processing of timber with chainsaws; reading manufacturer's instructions; and courses or conferences on international companies.

Table 5 shows the number of hours of training they received on the use and operation of chainsaws. Of the total workers surveyed (378), 57 say they do not know the number of hours of training they have received on the use and operations of chainsaws.

Table $\mathbf{5}$ Training in use and operation of chainsaws

\begin{tabular}{|l|c|c|}
\hline \multicolumn{1}{|c|}{ Chainsaw training time } & Frequency & Percentage, \% \\
\hline None & 22 & 5.8 \\
\hline Between 1 and 50 hrs & 159 & 42.1 \\
\hline Between 51 and 100 hrs & 51 & 13.4 \\
\hline Between 101 and 150 hrs & 16 & 4.2 \\
\hline Between 151 and 200 hrs & 10 & 2.7 \\
\hline More than 200 hrs & 9 & 2.4 \\
\hline Unknown & 57 & 15.1 \\
\hline Does not answer & 54 & 14.3 \\
\hline Total & 378 & 100 \\
\hline
\end{tabular}




\subsection{Questionnaire Section}

\subsubsection{Personal Protective Equipment}

Almost all respondents always use personal protective equipment (PPE); three out of four workers always inspect the state of personal protective equipment and two out of every three workers always carry out the maintenance of their personal protective equipment, as shown in Table 6.

\subsubsection{Chainsaw}

As for the chainsaw itself, as shown in Table 7, over half the workers always carry out maintenance to it, two out of three always know how to sharpen the teeth of the chainsaw, and perform these tasks daily.

\subsubsection{Work Techniques}

With regard to the work techniques, Table 8 shows that the majority of the respondents always refuel the chainsaw away from the work area and never smoke while refuelling. In relation to the question of whether they carry the chainsaw over their shoulders without their scabbards, the average of this question is 1.27. As for the question of whether they cut with the chainsaw pointing towards their legs or body, the average is at 1.17. It should also be noted that only $43 \%$ of the workers always use the right felling method, $32.3 \%$ take regular breaks to avoid distractions and $40.5 \%$ sometimes cut the fallen tree using log length marks on the trunk to help. In addition, before felling, the majority (320) said that they plan an escape route depending on the type of tree and the way it falls.

\subsubsection{Work at Height without Mobile Elevating Work Platforms}

In the case of work at height without lifting platforms or ladders, approximately two out of five workers always use lifelines, anchors, ropes, harnesses and retractable lanyards and they inspect their state before use. However, it was found that $15 \%$ of the workers use ladders when working with chainsaws, as shown in Table 9.

Table $\mathbf{6}$ Results of items on personal protective equipment

\begin{tabular}{|c|c|c|c|c|c|c|c|}
\hline \multirow{2}{*}{ Please indicate how often you perform the following tasks } & \multicolumn{6}{|c|}{ Results of responses } & \multirow{2}{*}{$\begin{array}{c}\begin{array}{c}\text { Descriptive } \\
\text { statistics }\end{array} \\
\bar{x}(\sigma)\end{array}$} \\
\hline & Always & Almost always & Sometimes & Hardly ever & Never & Unknown & \\
\hline \multirow{2}{*}{$\begin{array}{l}\text { You use personal protective equipment such as a hard hat, } \\
\text { safety gloves, hearing protectors..., No., \% }\end{array}$} & 355 & 22 & 1 & 0 & 0 & 0 & \multirow{2}{*}{$4.93(0.25)$} \\
\hline & 93.9 & 5.8 & 0.3 & 0.0 & 0.0 & 0.0 & \\
\hline \multirow{2}{*}{$\begin{array}{l}\text { You inspect the state of the personal protective equipment, } \\
\text { No., \% }\end{array}$} & 290 & 65 & 20 & 1 & 1 & 1 & \multirow{2}{*}{$4.70(0.60)$} \\
\hline & 76.7 & 17.2 & 5.3 & 0.3 & 0.3 & 0.3 & \\
\hline \multirow{2}{*}{$\begin{array}{l}\text { You carry out maintenance to the personal protective } \\
\text { equipment, No., \% }\end{array}$} & 250 & 70 & 45 & 6 & 4 & 3 & \multirow{2}{*}{$4.48(0.84)$} \\
\hline & 66.1 & 18.5 & 11.9 & 1.6 & 1.1 & 0.8 & \\
\hline
\end{tabular}

Table 7 Results of the items on the chainsaw

\begin{tabular}{|c|c|c|c|c|c|c|c|}
\hline \multirow{2}{*}{ Please indicate how often you perform the following tasks } & \multicolumn{6}{|c|}{ Results of responses } & \multirow{2}{*}{$\begin{array}{c}\begin{array}{c}\text { Descriptive } \\
\text { statistics }\end{array} \\
\bar{x}(\sigma)\end{array}$} \\
\hline & Always & Almost always & Sometimes & Hardly ever & Never & Unknown & \\
\hline \multirow{2}{*}{$\begin{array}{l}\text { You know how to sharpen the chainsaw teeth and do so daily, } \\
\text { taking into account the right angles, depth gauges, etc., No., \% }\end{array}$} & 231 & 52 & 56 & 14 & 19 & 6 & \multirow{2}{*}{$4.23(1.15)$} \\
\hline & 61.1 & 13.8 & 14.8 & 3.7 & 5.0 & 1.6 & \\
\hline \multirow{2}{*}{$\begin{array}{l}\text { You conduct maintenance operations to the chain catcher, } \\
\text { throttle trigger, spark plugs and air filters, chain brake and bar, } \\
\text { No., \% }\end{array}$} & 212 & 68 & 64 & 22 & 9 & 3 & \multirow{2}{*}{$4.20(1.07)$} \\
\hline & 56.1 & 18.0 & 16.9 & 5.8 & 2.4 & 0.8 & \\
\hline
\end{tabular}


Table 8 Results of the items on work techniques

\begin{tabular}{|c|c|c|c|c|c|c|c|}
\hline \multirow{2}{*}{ Please indicate how often you perform the following tasks } & \multicolumn{6}{|c|}{ Results of responses } & \multirow{2}{*}{$\begin{array}{c}\text { Descriptive } \\
\text { statistics } \\
\bar{x}(\sigma)\end{array}$} \\
\hline & Always & Almost always & Sometimes & Hardly ever & Never & Unknown & \\
\hline \multirow{2}{*}{$\begin{array}{l}\text { You refuel the chainsaw away from the work area and you do } \\
\text { not smoke while refuelling, No., \% }\end{array}$} & 302 & 41 & 15 & 3 & 16 & 1 & \multirow{2}{*}{$4.61(0.93)$} \\
\hline & 79.9 & 10.8 & 4.0 & 0.8 & 4.2 & 0.3 & \\
\hline \multirow{2}{*}{$\begin{array}{l}\text { You carry the chainsaw on your shoulder without the sheath } \\
\text { on it, No., \% }\end{array}$} & 9 & 7 & 14 & 19 & 327 & 2 & \multirow{2}{*}{$1.27(0.82)$} \\
\hline & 2.4 & 1.9 & 3.7 & 5.0 & 86.5 & 0.5 & \\
\hline \multirow{2}{*}{$\begin{array}{l}\text { Before felling, you plan an escape route depending on the type } \\
\text { of tree and way it falls, No., \% }\end{array}$} & 320 & 31 & 12 & 4 & 1 & 10 & \multirow{2}{*}{$4.80(0.56)$} \\
\hline & 84.7 & 8.2 & 3.2 & 1.1 & 0.3 & 2.6 & \\
\hline \multirow{2}{*}{$\begin{array}{l}\text { You use the right felling method, with the right auxiliary tools, } \\
\text { and you use hinges according to the diameter, appearance } \\
\text { and condition of the trunk, No., \% }\end{array}$} & 161 & 75 & 69 & 40 & 28 & 5 & \multirow{2}{*}{$3.80(1.29)$} \\
\hline & 42.6 & 19.8 & 18.3 & 10.6 & 7.4 & 1.3 & \\
\hline \multirow{2}{*}{$\begin{array}{l}\text { You cut with the chainsaw pointing towards your legs or body, } \\
\text { No., \% }\end{array}$} & 4 & 4 & 6 & 27 & 335 & 2 & \multirow{2}{*}{$1.17(0.60)$} \\
\hline & 1.1 & 1.1 & 1.6 & 7.1 & 88.6 & 0.5 & \\
\hline \multirow{2}{*}{$\begin{array}{l}\text { To cut up the fallen tree, you use log length marks on the trunk } \\
\text { to help you, No., \% }\end{array}$} & 62 & 57 & 153 & 40 & 61 & 5 & \multirow{2}{*}{$3.05(1.25)$} \\
\hline & 16.4 & 15.1 & 40.5 & 10.6 & 16.1 & 1.3 & \\
\hline \multirow{2}{*}{ You take regular breaks to avoid distractions, No., \% } & 122 & 95 & 112 & 19 & 17 & 13 & \multirow{2}{*}{$3.78(1.10)$} \\
\hline & 32.3 & 25.1 & 29.6 & 5.0 & 4.5 & 3.4 & \\
\hline
\end{tabular}

Table 9 Results of items on work at height without mobile elevating work platforms

\begin{tabular}{|c|c|c|c|c|c|c|c|}
\hline \multirow{2}{*}{ Please indicate how often you perform the following tasks } & \multicolumn{6}{|c|}{ Results of responses } & \multirow{2}{*}{$\begin{array}{c}\text { Descriptive } \\
\text { statistics } \\
\bar{x}(\sigma)\end{array}$} \\
\hline & Always & Almost always & Sometimes & Hardly ever & Never & Unknown & \\
\hline \multirow{2}{*}{ You use ladders when working with a chainsaw, No., \% } & 3 & 10 & 47 & 29 & 204 & 85 & \multirow{2}{*}{$1.56(0.94)$} \\
\hline & 0.8 & 2.6 & 12.4 & 7.7 & 54.0 & 22.5 & \\
\hline \multirow{2}{*}{$\begin{array}{l}\text { When working at height without an elevating work platform or } \\
\text { ladder, you use anchors, ropes, harnesses and retractable } \\
\text { lanyards and you inspect their state before use, No., \% }\end{array}$} & 160 & 27 & 16 & 13 & 43 & 119 & \multirow[b]{2}{*}{$3.95(1.54)$} \\
\hline & 42.3 & 7.1 & 4.2 & 3.4 & 11.4 & 31.5 & \\
\hline \multirow{2}{*}{$\begin{array}{l}\text { If you work at height without an elevating work platform or } \\
\text { ladder, you use a lifeline, No., \% }\end{array}$} & 147 & 33 & 16 & 11 & 43 & 128 & \multirow{2}{*}{$3.92(1.54)$} \\
\hline & 38.9 & 8.7 & 4.2 & 2.9 & 11.4 & 33.9 & \\
\hline
\end{tabular}

\subsubsection{Mobile Elevating Work Platforms}

As shown in Table 10, just over half the workers always mark off the work area and always stay in the basket at all times wearing the harness and protective equipment, without exceeding the rated load and with the corresponding support. Just under half the workers stated that, when the platform is moving, they always ensure that they have clear visibility at all times and they adapt the speed and maintain safety distances. A similar number of workers $(n=179)$ indicated that, before and after using the MEWP, they check the state of the safety devices and always park the MEWP properly after use.

\subsubsection{Winches}

As for winches, over half the workers always inspect the state of winch ropes and chains, they always 
Table 10 Results of items on work with mobile elevating work platforms

\begin{tabular}{|c|c|c|c|c|c|c|c|}
\hline \multirow{2}{*}{ Please indicate how often you perform the following tasks } & \multicolumn{6}{|c|}{ Results of responses } & \multirow{2}{*}{$\begin{array}{c}\begin{array}{c}\text { Descriptive } \\
\text { statistics }\end{array} \\
\bar{x}(\sigma)\end{array}$} \\
\hline & Always & Almost always & Sometimes & Hardly ever & Never & Unknown & \\
\hline \multirow{2}{*}{$\begin{array}{l}\text { Before and after using the mobile elevating work platform, } \\
\text { you check the state of the safety devices for any possible } \\
\text { defects or faults, No., \% }\end{array}$} & 179 & 42 & 28 & 10 & 16 & 103 & \multirow{2}{*}{$4.30(1.15)$} \\
\hline & 47.4 & 11.1 & 7.4 & 2.6 & 4.2 & 27.2 & \\
\hline \multirow{2}{*}{$\begin{array}{l}\text { You mark off the working area to keep others away and to } \\
\text { avoid high voltage power lines, No., } \%\end{array}$} & 235 & 31 & 12 & 5 & 7 & 88 & \multirow{2}{*}{$4.66(0.83)$} \\
\hline & 62.2 & 8.2 & 3.2 & 1.3 & 1.9 & 23.3 & \\
\hline \multirow{2}{*}{$\begin{array}{l}\text { You stay inside the basket at all times, wearing the harness } \\
\text { and protective equipment, without exceeding rated load and } \\
\text { with the corresponding support, No., \% }\end{array}$} & 193 & 33 & 9 & 3 & 23 & 117 & \multirow{2}{*}{$4.41(1.20)$} \\
\hline & 51.1 & 8.7 & 2.4 & 0.8 & 6.1 & 31.0 & \\
\hline \multirow{2}{*}{$\begin{array}{l}\text { When the platform is moving, you make sure you have clear } \\
\text { visibility at all times, you avoid reversing, and you adapt and } \\
\text { limit the speed to the terrain, always maintaining safety } \\
\text { distances, No., \% }\end{array}$} & 179 & 35 & 9 & 3 & 23 & 129 & \multirow[b]{2}{*}{4.38 (1.22) } \\
\hline & 47.4 & 9.3 & 2.4 & 0.8 & 6.1 & 34.1 & \\
\hline \multirow{2}{*}{$\begin{array}{l}\text { After use, you park the platform with all everything turned } \\
\text { off, making sure it is completely immobile, clean and in its } \\
\text { place, No., \% }\end{array}$} & 184 & 27 & 11 & 4 & 25 & 127 & \multirow[b]{2}{*}{4.35 (1.27) } \\
\hline & 48.7 & 7.1 & 2.9 & 1.1 & 6.6 & 33.6 & \\
\hline
\end{tabular}

Table 11 Results of items on winches

\begin{tabular}{|c|c|c|c|c|c|c|c|}
\hline \multirow{2}{*}{ Please indicate how often you perform the following tasks } & \multicolumn{6}{|c|}{ Results of responses } & \multirow{2}{*}{$\begin{array}{c}\text { Descriptive } \\
\text { statistics } \\
\bar{x}(\sigma)\end{array}$} \\
\hline & Always & Almost always & Sometimes & Hardly ever & Never & Unknown & \\
\hline \multirow{2}{*}{ You inspect the state of winch ropes and chains, No., \% } & 200 & 37 & 15 & 4 & 13 & 109 & \multirow{2}{*}{$4.51(1.01)$} \\
\hline & 52.9 & 9.8 & 4.0 & 1.1 & 3.4 & 28.8 & \\
\hline \multirow{2}{*}{$\begin{array}{l}\text { You take all necessary steps to avoid cuts, scrapes, } \\
\text { entrapment, falls from height, falls of loads or collapses, or } \\
\text { an overturned support or anchor structure, No., \% }\end{array}$} & 227 & 32 & 8 & 0 & 9 & 102 & \multirow{2}{*}{$4.69(0.81)$} \\
\hline & 60.1 & 8.5 & 2.1 & 0.0 & 2.4 & 27.0 & \\
\hline \multirow{2}{*}{$\begin{array}{l}\text { There is clear communication with the operator handling } \\
\text { the winch, No., \% }\end{array}$} & 208 & 35 & 12 & 5 & 7 & 111 & \multirow{2}{*}{$4.61(0.86)$} \\
\hline & 55.0 & 9.3 & 3.2 & 1.3 & 1.9 & 29.4 & \\
\hline
\end{tabular}

ensure clear communication with the operator handling the winch, and they always take all necessary steps to avoid injury or accidents.

\subsubsection{Emergencies}

In this last section on emergencies, as shown in Table 12, two out of every three workers always know how to conduct rescue operations in the event of trapped, hurt or injured people and four out of five stated that there is always a first aid kit in the workplace.

\subsection{Correlation Analysis}

In order to test the correlation between the factors analysed, different hypotheses were proposed and studied using non-parametric tests. On the one hand, it was analysed whether the behaviour related to chainsaw use reported by the workers in the questionnaire was related to the age of the workers. For this, different age groups were established (20-29 years, 30-39 years, 40-49 years, 50-59 years and more than 60 years) and average variables of worker responses were calculated for each of the seven sections of the questionnaire. The results showed that there are a significant differences $(p=0.05)$ in chainsaw use according to the age of the worker in terms of chainsaw maintenance $(\mathrm{H}$ de Kruskal-Wallis=9.843; $p=0.043)$, work at height without mobile elevating work platforms ( $\mathrm{H}$ de Kruskal-Wallis=10.466; $p=0.033$ ), mobile elevating 
Table 12 Results of items on emergencies

\begin{tabular}{|c|c|c|c|c|c|c|c|}
\hline \multirow{2}{*}{ Please indicate how often you perform the following tasks } & \multicolumn{6}{|c|}{ Results of responses } & \multirow{2}{*}{$\begin{array}{c}\begin{array}{c}\text { Descriptive } \\
\text { statistics }\end{array} \\
\bar{x}(\sigma)\end{array}$} \\
\hline & Always & Almost always & Sometimes & Hardly ever & Never & Unknown & \\
\hline \multirow{2}{*}{$\begin{array}{l}\text { You know how to conduct rescue operations in the case } \\
\text { of trapped, hurt or injured people (i.e. to provide } \\
\text { assistance, immobilise and move the victim to a safe } \\
\text { area), No., \% }\end{array}$} & 243 & 57 & 29 & 6 & 6 & 37 & \multirow[b]{2}{*}{$4.53(0.85)$} \\
\hline & 64.3 & 15.1 & 7.7 & 1.6 & 1.6 & 9.8 & \\
\hline \multirow{2}{*}{ There is a first aid kit in the workplace, No., \% } & 300 & 37 & 10 & 1 & 9 & 21 & \multirow{2}{*}{$4.73(0.75)$} \\
\hline & 79.4 & 9.8 & 2.6 & 0.3 & 2.4 & 5.6 & \\
\hline
\end{tabular}

work platforms (H de Kruskal-Wallis=15.625; $p=0.004)$, winches $(\mathrm{H}$ de Kruskal-Wallis=18.679; $p=0.001)$ and emergency ( $\mathrm{H}$ de Kruskal-Wallis=14.551; $p=0.006$ ). However, no significant differences $(p=0.05)$ by age were found in the case of the use of personal protective equipment $(\mathrm{H}$ de Kruskal-Wallis $=0.881 ; p=0.927$ ) and the work techniques applied ( $\mathrm{H}$ de Kruskal-Wallis=3.035; $p=0.552$ ).

In addition, other correlations were explored. In this sense, it is noteworthy that it was found that, according to the information reported by the workers, there are significant differences $(p=0.05)$ between the existence of a first aid kit in the workplace by type of company in which the worker claims to work ( $\mathrm{H}$ de Kruskal-Wallis=17.568; $p=0.004)$. However, there are no significant differences $(p=0.05)$ in reported knowledge of emergency manoeuvres according to the periodicity of chainsaw use reported by the worker ( $\mathrm{H}$ de Kruskal-Wallis $=6.752 ; p=0.150$ ) or the type of company in which the worker claims to work (H de KruskalWallis=9.503; $p=0.091$ ).

A significant difference $(p=0.05)$ was also found in the use of a lifeline in work at height, without an elevating work platform or ladder, according to the frequency of chainsaw use ( $\mathrm{H}$ de Kruskal-Wallis=22.774; $p=0.000$ ). Thus, the more frequent the use of a chainsaw, the less frequent the use of a lifeline. However, no significant differences $(p=0.05)$ were found in the use of anchors, ropes, harnesses and retractable lanyards and their inspection (H de Kruskal-Wallis=5.131; $p=0.274$ ). Finally, the use of ladders also showed a significant difference $(p=0.05)$ with respect to the frequency of chainsaw use (H de Kruskal-Wallis=13.946; $p=0.007)$. In this case, those who reported using ladders the least were the workers who used the chainsaw daily, while those who reported using them the most were those who reported using the chainsaw once a month or once a week.

\section{Discussion}

As for the analysis of the weaknesses in the training in chainsaw operation at work in Andalusia, Spain, work-related shortcomings have been detected in relation to the different aspects that were analysed. With regard to the personal information of the worker who uses a chainsaw analysed in the preliminary section, the results of the questionnaire show that $96 \%$ of the workers who participated in the study were between 30 and 59 years old, with $48 \%$ between the ages of 40 and 49 . This is in line with the claims of other authors such as Blombäck et al. (2003), who indicated that this type of job is an unattractive for young people. Likewise, a significant correlation is found between the age of the chainsaw user and some of the main risk factors identified. It should also be noted that $10.1 \%$ of the respondents perform chainsaw operations at least once a month, $9.3 \%$ of them use it daily and $20 \%$ weekly. This last data seems to indicate the importance of the chainsaw in their work. In this sense, it should be considered that working hours have a great influence on the physical and mental state of workers (Albizu-Urionabarrenetxea et al. 2013, Lilley et al. 2002). The findings of this study show that $53.2 \%$ of workers used a chainsaw for several months per year. This could be due to the seasonal nature of the work with a chainsaw, which leads to the majority of workers not developing their activity continuously and permanently. In fact, previous studies coincide in pointing out this seasonality as a risk factor in performing chainsaw tasks (Picchio et al. 2010, Montorselli et al. 2010, Wang et al. 2003).

Further analysis of the personal information showed that $85.4 \%$ of the workers were employed in public companies. In principle, the fact that the company is public or private should not influence the use of the chainsaw in terms of safety. Nevertheless, Montorselli et al. (2010) found that public crews took significantly less risks and the riskiest ones were semi-private crews 
followed by private and consortium crews. According to the authors of that study, best safety performance by public crews could be related to the stronger commitment of public management to safety and to the fact that public organisations administered formal safety training to their crews. In line with this, in the specific case of this study, the majority of workers, who worked mostly in public companies, reported having received training in occupational health and safety and in use and operation of chainsaw. Despite this, there were deficiencies in the knowledge acquired by the workers in some subjects related to safety. For example, the results of this research show that only $31.5 \%$ of workers surveyed had learned to use a chainsaw on training courses. The rest had learned by themselves or from a coworker in the company where they worked. It is important to note that, with regards to training and education, there is currently no minimum specific and compulsory training for the chainsaw workers. There is only the basic training in occupational safety and health defined by European Directive 89/391/CEE (European Council 1989) on the introduction of measures to encourage improvements in the safety and health of workers at work. Then, all workers using a chainsaw would have to know how to use it safely and how to comply with occupational health and safety legislation. To guarantee that this is fulfilled and to ensure that all workers who use the chainsaw have adequate training, it would be advisable to provide regular training in a common framework.

The second part of the questionnaire focused on analyzing the knowledge of the workers who use the chainsaw. This information could be helpful for the regulation of training in this regard. The results obtained in the questionnaire section have clearly demonstrated that almost all respondents always use PPE; however some respondents expressed that they did not use it correctly or even did not use it all the time. This data is confirmed by authors such as Albizu-Urionabarrenetxea et al. (2013), who argue that there is still a minority of workers who do not use the prescribed PPE. However, these same authors affirm that it would be essential to adapt the Personal Protection Equipment to the working conditions and improve the awareness of its correct use.

Regarding the use and maintenance of the chainsaw, almost $9 \%$ of the workers surveyed never or hardly ever perform the sharpening or maintenance of chain catcher, throttle trigger, spark plugs and air filters of the chainsaw and only $16.9 \%$ sometimes take it into account, thus confirming what was exposed by reference authors (Albizu-Urionabarrenetxea et al. 2013, Robb and Cocking 2014), who found an absence of proper maintenance of this equipment under controlled safety conditions.

When workers were asked about the techniques, the results showed obvious deficiencies related to the felling methods and bucking of felled trees. In short, in accordance with the theories of Thelin (2002), Salminen et al. (1999) and Peters (1991), one of the main causes of accidents with chainsaws is ignorance of the proper work techniques.

The highest rate of fatal accidents occurring in the use of chainsaw is due to falls at height (Robb and Cocking 2014). In the questionnaire section dealing with work at height without MEWP, MEWP and winches, the percentage of workers who did not respond was high when compared with the other sections, with a figure of between $22.5 \%$ and $34.1 \%$. It was hypothesised that these workers do not work at height and do not use winches or MEWP, as indicated by some of them in their comments. Notably, even though the European Directive 2009/104/EC (European Parliament and of the Council 2009) prohibits workers from using a chainsaw on a ladder, it was found that $15 \%$ of the workers did so in their daily work. Even so, the results show that the more frequent the use of the chainsaw, the less frequent the use of the ladder.

Finally in the questionnaire section dealing with emergencies, the lack of knowledge regarding rescue operations is detected. The low response rate in the emergency section $(9.8 \%$ gave no answer in the section on rescue and $5.6 \%$ on first aid kit) is not justified since all workers may be affected at some time by a critical situation in which they need to use the rescue operations or the first aid kit. Therefore, they must be trained to do so in order to be able to respond to these situations. Furthermore, the results obtained show a relationship between the existence of a first aid kit and the type of company where the interviewees work. There is no such a relationship between the type of company and the rescue operations in case of emergency.

The knowledge about safety emergency plan is very important because these documents contain all the information for proper safety and health management. For example, with the emergency plan, workers can know the evacuation routes that are essential in an emergency. Despite the importance of the need for proper planning and execution of emergency actions, authors like Robb and Cocking (2014) highlight that there is still not a regulated training in Europe for the chainsaw operations in rescue or emergency situations.

Therefore, a general common deficiency in all the aspects studied was the lack of safety inspections of both the state of the equipment, the work techniques and the PPEs to be used. 


\section{Conclusions}

The purpose of this research was to determine whether occupational health and safety training in the use of the chainsaw as a work equipment is effective, and to identify their weaknesses in the training received by chainsaw workers. This particular aspect has not been addressed so far, so the findings of this research could offer original contribution by determining whether it could stimulate occupational health and safety implementation through the improvement of the weaknesses detected in the training of workers who use the chainsaw at work. Thus, learning performance and training transfer are significant measurement to determine training effectiveness because the main purpose of providing employee training is to increase employees' knowledge, skills, and attitudes and finally use it to improve job performance.

The conclusions of this research indicate that the lack of training detected on rescue techniques and work at height is of particular importance, since these are the aspects of special risk for workers' health, which could lead to accidents with severe injuries. These results evidence that there is a need to regulate chainsaw operator training. With this study, a first step has been taken towards the identification of mandatory minimum competences for chainsaw workers. So, minimum compulsory training contents should be developed for workers who use chainsaws as work equipment, regardless of the industry they work in. Consequently, a training manual should be developed including all of these contents to be used as a reference document. This would be a significant improvement for the protection of chainsaw operators' health and safety.

\section{Acknowledgments}

Authors would like to acknowledge the support of the project VET-SAFETY project 2014-2017, „Vocational education \& training standards in agriculture, forestry \& environmental safety at heights«. The project is supported by the EU Erasmus + programme \& ABA International. Also, we acknowledge to the Andalusian Government, the Junta de Andalucía, and, in particular, the Agencia de Medio Ambiente y Agua (AMAYA) and the Conserjería de Empleo, Empresa y Comercio, through the Diputacion Provincial de Málaga.

\section{References}

ABA International-European Chainsaw Standards. Available from: www.aba-skills.com

Albizu-Urionabarrenetxea, P., 2012. Diagnóstico de la seguridad en los aprovechamientos forestales a partir de regist- ros empresariales, bases de datos oficiales y muestreos de campo: propuestas de actuación. Doctoral Thesis, Superior Technical School of Engineering of Mountains, Forest and Natural Environment, Polytechnic University of Madrid (Spain), May.

Albizu-Urionabarrenetxea, P.A., Esteban, E.T., Zaldívar, J.U., Carretero, M.F., 2010: Diagnóstico de la seguridad en los aprovechamientos forestales a partir de registros empresariales, bases de datos oficiales y muestreos de campo. Propuestas de actuación. For Syst 19(2): 221-233.

Albizu-Urionabarrenetxea, P., Tolosana-Esteban, E., RomanJordan, E., 2013: Safety and health in forest harvesting operations. Diagnosis and preventive actions. A review. For Syst 22(3): 392-400. http://dx.doi.org/10.5424/fs/2013223-02714

Allman, M., Jankovský, M., Allmanová, Z., Ferenčík, M., Messingerová, V., Vlčková M., Stoilov S., 2017: Work accidents during cable yarding operations in Central Europe 2006-2014. For Syst 26(1): 13 p. https://doi.org/10.5424/ fs/2017261-10365

Ambrosio Torrijos, Y., Tolosana Esteban, E., Vignote Peña, S., Garasa, M., 2001: Analysis of occupational health and safety in forest harvesting and thinning in Spain. Chapingo Journal 7: 55-65.

Axelsson, S., 1998: The mechanization of logging operations in sweden and its effect on occupational safety and health. J For Eng 9(2): 25-31. https://doi.org/10.1080/08435243.1998.1 0702715

Bell, J.L., 2002. Changes in logging injury rates associated with use of feller-bunchers in west virginia. J Safety Res 33(4): 463-471. https://doi.org/10.1016/S0022-4375(02)000488

Bellmunt, J.J., 1986: NTP-167. Aparejos, cabrias y garruchas. Instituto Nacional de Seguridad e Higiene en el Trabajo.

Bentley, T.A., Parker, R., Ashby, L., Moore, D., Tappin, D., 2002: The role of the new zealand forest industry injury surveillance system in a strategic ergonomics, safety and health research programme. Appl Ergon 33(5): 395-403. https://doi. org/10.1016/S0003-6870(02)00037-6

Blombäck, P., Poschen, P., Lövgren, M., 2003: Employment Trends and Prospects in the European Forest Sector. Geneva Timber and Forest Discussion Papers, European Forest Sector Outlook Study (EFSOS) 9. United Nations Publications.

Cabeças, J.M., 2006: An approach to health and safety in E.U. forestry operations - Hazards and preventive measures. Enterprise and Work Innovation Studies 3: 19-31.

Cividino, S.R.S., Colantoni, A., Vello, M., Dell'Antonia, D., Malev, O., Gubiani, R., 2015: Risk Analysis of Agricultural, Forestry and Green Maintenance Working Sites. Contemporary Engineering Sciences 27(8): 1257-1266. http://dx.doi. org/10.12988/ces2015.56182

Cividino, S.R.S., Maroncelli, E., Vello, M., Gubiani, R., Snidero, I., Pergher, G., 2012: Accident analysis during the chainsaw use: Prevention and protection measures to reduce in- 
juries. Paper presented at the International Conference RAGUSA SHWA, Ragusa-Italy, Safety Health and Welfare in Agriculture and in Agro-Food Systems 157-164.

Corral, Y., 2009: Validez y confiabilidad de los instrumentos de investigación para la recolección de datos. Universidad de Carabobo. Rev Cien Educ 19(33): 228-247.

Damalas, C.A., Koutroubas, S.D., Abdollahzadeh, G., 2019: Drivers of personal safety in agriculture: a case study with pesticide operators. Agriculture 9(2): 34. https://doi:10.3390/ agriculture 9020034

Enez, K., Topbas, M., Acar, H.H., 2014: An evaluation of the occupational accidents among logging workers within the boundaries of Trabzon Forestry Directorate, Turkey. Int J Ind Ergon 44(5): 621-628. https://doi.org/10.1016/j.ergon.2014.07.002

European Council, 1989: European Directive 89/391/EEC of 12 June: Introduction of measures to encourage improvements in the safety and health of workers at work. Official Journal of the European Communities 32 (LI 83), 29 June, Luxembourg.

European Parliament and of the Council, 2009: Directive 2009/104/EC of 16 September 2009 concerning the minimum safety and health requirements for the use of work equipment by workers at work (second individual Directive within the meaning of Article 16(1) of Directive 89/391/EEC).

Hammig, B., Jones, C., 2015: Epidemiology of chain saw related injuries, United States: 2009 through 2013. Advances in emergency medicine.

Landekić, M., Martinić, I., Bakarić, M., Pentek, T., Poršinsky, T., Šporčić, M., 2018: Current State and Improvement Potential of Forestry Workers Training in Croatia. Croat J For Eng 39(2): 289-298.

Lefort, A.J., de Hoop, C.P., Pine, J.C., 2003: Characteristics of injuries in the logging industry of Louisiana, USA: 1986 to 1998. Int J Forest Eng 14(2): 75-89. https://doi.org/10.1080/1 4942119.2003.10702480

Lilley, R., Feyer, A.M., Kirk, P., Gander, P., 2002: A survey of forest workers in New Zealand. Do hours of work, rest, and recovery play a role in accidents and injury?. J Safety Res 33(1): 53-71. https://doi.org/10.1016/S0022-4375(02)00003-8

Ministry of Labour and Social Security, 2011: Real Decreto 682/2011, de 13 de mayo, por el que se establecen seis certificados de profesionalidad de la familia profesional Agraria que se incluyen en el Repertorio Nacional de certificados de profesionalidad y se actualizan los certificados de profesionalidad establecidos como anexos I, II, IV, VI, VII, VIII y XII en el Real Decreto 1375/2008 de 1 de agosto, el certificado de profesionalidad establecido como anexo I en el Real Decreto 1965/2008 de 28 de noviembre, y el certificado de profesionalidad establecido como anexo III en el Real Decreto 1211/2009, de 17 de julio.

Montorselli, N.B., Lombardini, C., Magagnotti, N., Marchi, E., Neri, F., Picchi, G., Spinelli, R., 2010: Relating safety, productivity and company type for motor-manual logging op- erations in the Italian Alps. Accident Anal Prev 42(6): 20132017. https://doi.org/10.1016/j.aap.2010.06.011

Neely, G., Wilhelmson, E, 2006: Self-reported incidents, accidents, and use of protective gear among small- scale forestry workers in Sweden. Safety Sci 44(8): 723-732. https:// doi.org/10.1016/j.ssci.2006.03.002

Nieuwenhuis, M., Lyons, M., 2002: Health and Safety Issues and Perception of Forest Harvesting Contractors in Ireland. Int J Forest Eng 13(2): 69-76. https://doi.org/10.1080/149421 19.2002.10702464

Pardo Ferreira, M.C., Rubio Romero, J.C., Lopez Arquillos, A., Galindo Reyes, F.C., 2017: Identify minimum training requirements for the chainsaw operators. In book: Sho 2017: V International Symposium on Occupational Safety and Hygiene, Guimaraes Portugal.

Peters, P., 1991: Chainsaw Felling Fatal Accidents. Transactions of the ASAE 34(6): 2600-2608. https://doi. org/10.13031/2013.31912)@1991

Picchio, R., Blasi, S., Sirna, A., 2010: Survey on Mechanization and Safety Evolution in Forest Works in Italy. International Conference Ragusa SHWA2010. September 16-18 p.

Potočnik, I., Poje, A., 2017: Forestry ergonomics and occupational safety in high ranking scientific journals from 20052016. Croat J For Eng 38(2): 291-310.

Robb, W., Cocking, J., 2014: Review of European chainsaw fatalities, accidents and trends. Arboricultural Journal: The International Journal of Urban Forestry 36(2): 103-126. https://doi.org/10.1080/03071375.2014.913944

Robb, W., 2011a: ECC 1: Chainsaw Maintenance \& Crosscutting Techniques. European Chainsaw Certification. ABA International

Robb, W., 2011b: ECC 2: Basic Tree Felling Techniques. European Chainsaw Certification. ABA International

Robb, W., 2011c: ECC 3: Advanced Tree Felling Techniques. European Chainsaw Certification. ABA International.

Robb, W., 2011d: ECC 4: Windblown \& Damaged Trees. European Chainsaw Certification. ABA International.

Salminen, S., Klen, T., Ojanen, K., 1999: Risk taking and accident frequency among Finnish forestry workers. Safety Sci 33(3): 143-153. https://doi.org/10.1016/S0925-7535(99)00029-6

Shaffer, R., Milburn, J., 1999: Injuries on Feller-Buncher/ Grapple Skidder Logging Operations in the South- Eastern United States. Forest Prod J 49(7/8): 24.

Tamboreno, J.M., 1989: NTP-239. Escaleras Manuales. Instituto Nacional de Seguridad e Higiene en el Trabajo.

Tamboreno, J.M., Mayo, J.M., Etxebarria, J.R., 2015: NTP1040: Plataformas Elevadoras Móviles de Personal (PEMP). Instituto Nacional de Seguridad e Higiene en el Trabajo.

Thelin, A., 2002: Fatal accidents in Swedish farming and forestry, 1988-1997. Safety Sci 40(6): 501-517. https://doi. org/10.1016/S0925-7535(01)00017-0 
Wang, J., Bell, J.L., Grushecky, S.T., 2003: Logging injuries for a 10-year period in Jilin Province of the People's Republic of China. J Safety Res 34(3): 273-279. https://doi. org/10.1016/S0022-4375(03)00024-0
Wilhelmson, E., StaalWästerlund, D., Burström, L., Bylund, P-O., 2005: Public health effects of accidents in selfemployed forestry work. Small-Scale Forestry 4(4): 427-435. https://doi. org/10.1007/s11842-005-0026-5

(C) 2022 by the authors. Submitted for possible open access publication under the terms and conditions of the Creative Commons Attribution (CC BY) license (http://creativecommons.org/licenses/by/4.0/).

Received: October 26, 2020

Accepted: February 28, 2021
Authors' addresses:

Prof. María del Carmen Pardo Ferreira, PhD e-mail: carmenpf@uma.es

Prof. Francisco Salguero Caparrós, PhD *

e-mail: fsalguero@uma.es

Prof. Juan Carlos Rubio Romero, PhD

e-mail: juro@uma.es

University of Málaga

School of Industrial Engineering

Department of Business Management

C/ Dr. Ortiz Ramos s/n, Campus de Teatinos 29071, Malaga

SPAIN

Prof. Jesús Antonio Carrillo Castrillo, PhD

e-mail: jcarrillo3@us.es

University of Sevilla

School of Industrial Engineering

Department of Industrial Organization and Business Management II

Camino de los Descubrimientos sn

41092, Sevilla

SPAIN

* Corresponding author 